\title{
In vitro Evaluation and Sensitivity of Antibiotics and Fungicides against Xanthomonas axonopodis pv. punicae
}

\author{
Sumant H. Kabade*, R. W. Ingle, Punam N. Usendi amd Rahul S. Shete \\ Department of Plant Pathology, Dr. Panjabrao Deshmukh Krishi Vidyapeeth, \\ Akola- 444104 (M.S.), India \\ *Corresponding author
}

\section{A B S T R A C T}

\section{Keywords}

Xanthomonas axonopodis pv.,

Punica granatum,

Bacterium,

Streptomycine

sulphate,

Copper oxychlorite,

Inhibition zone,

Streptocycline

Article Info

Accepted:

20 July 2020

Available Online:

10 August 2020
Cultivation of high yielding varieties of pomegranate with intensive care and management in the recent past under irrigated condition with early stage exploitation of plants has lead to certain severe pest and disease problems. Bacterial blight disease of pomegranate caused by Xanthomonas axonopodis pv. punicae is one of the most destructive disease of pomegranate (Punica granatum) inflicting considerable quantitative and qualitative losses. Mostly the disease occurred on leaves, stems and fruits. Extensive agricultural practices along with large amount of pesticide as well as antibiotic are required to control this disease. The antibiotic sensitivity against eight isolates was studied by paper disk inhibition method. Streptomycine sulphate (250ppm) + COC (2500ppm) was significantly superior than all the treatments showing maximum inhibition zone in all eight isolates of Xanthomonas axonopodis pv. punicae.

\section{Introduction}

Pomegranate (Punica granatum L.) is a favourite table fruit in tropical and subtropical regions of the world which belongs to family Punicae. Among the major diseases leaf spot, fruit spot and will results in reduction of pomegranate fruit yield and put the growers in to hardship. Pomegranate grows very well on the moderately alkaline soils as well as slightly acidic soils. Bacterial blight infection results in appearance of water soaked oily spot symptoms on leaves, stems and fruits which consequently decreases fruit production and market value. The continuous presence of the pathogen in the orchard throughout the season has led to many fold speculations on possible survival of the pathogen on some alternate hosts grown in and around the garden. Severity of incidence 
and losses varies among different isolates and influenced by existing climatic conditions and geographical distribution (Mondal and Sharma, 2009; Mondal and Singh, 2009; Petersen et al., 2007; Mondal et al., 2012).

\section{Materials and Methods}

\section{Collection of diseased sample and isolation of pathogen}

The bacterial blight diseased samples were collected from different districts of Maharashtra state. The isolate of pathogen was obtained from infected leaves of Pomegranate showing typical symptoms of bacterial blight by tissue isolation method. A bacterial suspension of each specimen was then cultured on Nutrient Sucrose Agar (NSA) medium. Following incubation, colonies similar to Xanthomonas were maintained on NSA medium at room temperature by adopting subsequent subculturing at periodical and regular intervals. Three days old cultures were used for further studies.

\section{Pathogenicity test of the isolate}

For this study the healthy seedling of Pomegranate cultivar 'Bhagwa' was obtained from the central nursery of state agriculture university P.D.K.V. Akola, Dist. - Akola, Maharashtra state. The seedling was grown under aseptic in vitro condition and veinlets of some leaves were injected with 48 hold bacterial suspension with the help of sterile syringe. Some plant leaves were injured by sharp needle and inoculated by spraying bacterial suspension. The inoculated plants were covered with polythene sheets and incubated for $10-12$ days at 25 to $28^{\circ} \mathrm{C}$ temperature. After 10- 12 days observations made for typical symptoms of bacterial blight on leaves, the organism was reisolated from artificially inoculated leaves and used for furtherantib1 acterial studies.
In vitro evaluation and sensitivity test of antibiotics \& fungicides against Xanthomonas axonopodi spv. punice by Paper disc method

Different chemicals at concentration 100, 300, $500 \mathrm{ppm}$ were evaluated in vitro applying inhibition zone technique (paper disc method) and using Nutrient Agar (N.A.) as basal culture medium. Fresh Nutrient Agar medium was prepared and dispersed in $100 \mathrm{ml}$ quantities in conical flask (200 ml. Cap.), plugged and autoclaved at $15 \mathrm{lbs} / \mathrm{cm} 2$ pressure for 15-20 minute. The desired concentration of chemicals i.e. 100, 300, 500 ppm was prepared by using appropriate quantities of chemical required for 100, 300, $500 \mathrm{ppm}$ concentration. In this desire concentration of chemicals $5 \mathrm{~mm}$ discs of Whatman No. 1 filter paper was dipped for few minutes. After sterilization of media, it was allowed to cool down to $35^{\circ} \mathrm{C}$ before pouring. Approximately $20 \mathrm{ml}$ liquid media was poured in previously sterilized Petri plates and allowed them to solidify. Pouring of plates were always be done by using Laminar Air Flow cabinet under aseptic condition. After solidification of media of Petri plates, the bacterial suspension was spread on Nutrient Agar with glass spreader. After uniform spreading of bacterial suspension $5 \mathrm{~mm}$ disc of Whatman No.1 filter paper previously dipped in desired concentration of chemicals was placed in centre of medium. Three replication for each concentration of chemical was maintained. The paper disc soaked in sterile distilled water served as control Three replication for each concentration of chemical was maintained. The paper disc soaked in sterile distilled water served as control.

All these Petri plates after treatment were incubated at $28 \pm 2{ }^{\circ} \mathrm{C}$ for 48 hours. Observation on radial growth of test pathogen. 


\section{Result and Discussion}

\section{Isolation and pathogenicity test}

Plates showing well separated, typical, yellow, mucoid, colonies of Xanthomonas bacterium were used to check pathogenicity on leaves of Pomegranate to confirm the isolate. After inoculation of pathogen in seedlings, seedlings were covered with plastic bags for maintain humidity for 3-4 days. The symptoms of the disease were developed within 10 to 18 days after inoculation on leaves small, water soaked, brown to black coloured lesions, which later on developed into angular to irregular shaped spots along the veins and veinlets of the leaf lamina. The re-isolation attempted from artificially infected / diseased plant tissues on Nutrient Agar consistently yielded $X$. axonopodis pv. punicae, thus fulfilling Koch's postulates and association of $X$. axonopodis pv. punicae with pomegranate was confirmed.

Pathogenic variability among different isolates of Xanthomonas axonopodi spv. punicae

Amongst eight isolates Xap-3 isolate had more lesion size i.e. $3.5 \mathrm{~mm}$ after 18 days of inoculation which showed water soaked circular to irregular dark brown spots with yellow halo symptoms followed by Xap-7 which showed $1.5 \mathrm{~mm}$ lesion size after 18 days after inoculation showing water soaked circular to irregular, light brown spots. The data is Presented in Table 1.

In vitro evaluation and sensitivity test of antibiotics \& fungicides against Xanthomonas axonopodispv. punice isolates

The sensitivity of antibiotics and fungicides was tested against eight isolates of Xanthomonas axonopodis pv. punicae (Xap-1 to Xap-8) by Paper disc inhibition method and data is Presented in Table 2 and Fig. 2. The streptocycline used in different concentration viz; 100, 250, $500 \mathrm{ppm}$. The results (Table 2) revealed that lower concentration of streptocycline i.e. $100 \mathrm{ppm}$ showed maximum growth inhibition in Xap-2 i.e $15.67 \mathrm{~mm}$ whereas the minimum growth inhibition was observed in Xap-1 i.e $6.00 \mathrm{~mm}$. For the concentration $250 \mathrm{ppm}$, maximum inhibition was seen in Xap-8 $(20.67 \mathrm{~mm})$ and minimum inhibition in Xap-7 $(11.67 \mathrm{~mm})$. The higher concentration of streptocycline i.e. $500 \mathrm{ppm}$ reported maximum inhibition in Xap-2 $(23.67 \mathrm{~mm})$ and minimum inhibition in Xap-1 $(18.67 \mathrm{~mm})$. The results showed that COC and Salicylic acid did not inhibit the growth which shows that isolates are not sensitive to COC and Salicylic acid. The results (Table 2, Fig 2) revealed that among the isolates Xap-6 $(39 \mathrm{~mm})$ showed maximum growth inhibition whereas minimum growth inhibition was shown by xap-8 $(28.67 \mathrm{~mm})$. Streptocycline $250 \mathrm{ppm}+$ COC $2500 \mathrm{ppm}$ showed maximum growth inhibition in Xap-4 (24.67) and minimum inhibition in Xap-2 $(21.67 \mathrm{~mm})$. The findings (Table 2, Fig. 2) revealed that Streptomycine sulphate 250ppm + COC 2500ppm (T8) was significantly superior over rest of the treatments showing maximum growth inhibition zone $(39 \mathrm{~mm})$ in Xap-6, followed by Xap-2 $(34.67 \mathrm{~mm})$. Whereas growth inhibition zone was minimum in Xap$8(28.67 \mathrm{~mm})$.

Similar results observed by Abhang et al., (2015). The efficacy of bioagents, botanicals and chemicals was studied by paper disc method. The Copper oxychloride $(0.2 \%)+$ streptomycin sulphate (200 ppm) was found significantly effective in inhibiting growth of Xanthomonas axonopodis $p v$. citri. Raju et al., (2012) carried out investigation to screen the different bactericides against Xanthomonas axonopodis $p v$. punicae. The inhibition zone of $3.3 \mathrm{~cm}$ was observed in the treatment of Streptocycline + Copper oxychloride. 
Ambadkar et al., (2015) studied in vitro efficacy of different antibiotics for management of bacterial blight and disease of pomegranate caused by Xanthomonas axonopodis $p v$. punicae. They found that antibiotic streptocycline showed maximum inhibition zone of 22.21 and 31.00 per cent at 250 and $500 \mathrm{ppm}$ against Xanthomonas axonopodispv. punicae followed by tetracycline (18.26 and $27.53 \%)$ and bacterinol (17.40 and $27.15 \%)$. Abhang et al., (2015), the efficacy of bioagents, botanicals and chemicals was studied by paper disc method. The Copper oxychloride $(0.2 \%)+$ streptomycin sulphate $(200 \mathrm{ppm})$ was found significantly effective in inhibiting growth of bacteria.

Table.1 List of different isolates collected from various villages of Maharashtra state

\begin{tabular}{|l|l|l|l|l|l|l|}
\hline Sr. no & $\begin{array}{l}\text { Name of } \\
\text { isolate }\end{array}$ & $\begin{array}{c}\text { Name of } \\
\text { Village }\end{array}$ & \multicolumn{1}{|c|}{ Taluka } & \multicolumn{1}{|c|}{ District } & \multicolumn{1}{|c|}{ Pathogen } & $\begin{array}{c}\text { Affected } \\
\text { plant part }\end{array}$ \\
\hline $\mathbf{1}$ & Xap-1 & Mardi & Man & Satara & $\begin{array}{l}\text { Xanthomonas } \\
\text { axonopodispv.punicae }\end{array}$ & Leaf \\
\hline $\mathbf{2}$ & Xap-2 & Anjangaon & Mhada & Solapur & $\begin{array}{l}\text { Xanthomonas } \\
\text { axonopodispv.punicae }\end{array}$ & Leaf \\
\hline $\mathbf{3}$ & Xap-3 & Agoti -1 & Indapur & Pune & $\begin{array}{l}\text { Xanthomonas } \\
\text { axonopodispv.punicae }\end{array}$ & Leaf \\
\hline $\mathbf{4}$ & Xap-4 & Bherdapur & Newasa & Ahmednagar & $\begin{array}{l}\text { Xanthomonas } \\
\text { axonopodispv.punicae }\end{array}$ & Fruit \\
\hline $\mathbf{5}$ & Xap-5 & Satephal & Jafrabad & Jalna & $\begin{array}{l}\text { Xanthomonas } \\
\text { axonopodispv.punicae }\end{array}$ & Leaf \\
\hline $\mathbf{6}$ & Xap-6 & Kolara & Chikhali & Buldhana & $\begin{array}{l}\text { Xanthomonas } \\
\text { axonopodispv.punicae }\end{array}$ & Leaf \\
\hline $\mathbf{7}$ & Xap-7 & Ekamba & Malegaon & Washim & $\begin{array}{l}\text { Xanthomonas } \\
\text { axonopodispv.punicae }\end{array}$ & Leaf \\
\hline $\mathbf{8}$ & Xap-8 & Akola & Akola & Akola & $\begin{array}{l}\text { Xanthomonas } \\
\text { auxonopodispv.punicae }\end{array}$ & Leaf \\
\hline
\end{tabular}

\begin{tabular}{|c|c|l|c|}
\hline Sr. No & $\begin{array}{c}\text { Treatment } \\
\text { No }\end{array}$ & \multicolumn{1}{|c|}{ Name of chemicals } & $\begin{array}{c}\text { Concentration of chemicals } \\
\text { (ppm) }\end{array}$ \\
\hline $\mathbf{1}$ & $\mathbf{T 1}$ & Streptomycin sulphate & 100 \\
\hline $\mathbf{2}$ & $\mathbf{T 2}$ & Streptomycin sulphate & 250 \\
\hline $\mathbf{3}$ & $\mathbf{T 3}$ & Streptomycin sulphate & 500 \\
\hline $\mathbf{4}$ & $\mathbf{T 4}$ & Streptocycline & 100 \\
\hline $\mathbf{5}$ & $\mathbf{T 5}$ & Streptocycline & 250 \\
\hline $\mathbf{6}$ & $\mathbf{T 6}$ & Streptocycline & 500 \\
\hline $\mathbf{7}$ & $\mathbf{T 7}$ & Copper Oxychlorite & 2500 \\
\hline $\mathbf{8}$ & $\mathbf{T 8}$ & Streptomycin sulphate + Copper oxychlorite & $250+2500$ \\
\hline $\mathbf{9}$ & $\mathbf{T}$ & Streptocycline + Copper oxychlorite & $250+2500$ \\
\hline $\mathbf{1 0}$ & $\mathbf{T 1 0}$ & Salicyclic acid & 200 \\
\hline $\mathbf{1 1}$ & Control & & \\
\hline
\end{tabular}


Table.2 Pathogenic variability among different isolates of Xanthomonas axonopodis pv. punicae on Pomegranate 45-60 day old seedlings

\begin{tabular}{|c|c|c|}
\hline \multirow[t]{2}{*}{ Sr. No } & \multirow[t]{2}{*}{ Isolates } & Lesion size $(\mathrm{mm})$ \\
\hline & & After 18 days \\
\hline 1 & Xap1 & 3 \\
\hline 2 & Xap2 & 3 \\
\hline 3 & Xap3 & 3.5 \\
\hline 4 & Xap4 & 3 \\
\hline 5 & Xap5 & 2 \\
\hline 6 & Xap6 & 2 \\
\hline 7 & Xap7 & 1.5 \\
\hline 8 & Xap8 & 2 \\
\hline
\end{tabular}


Table.3 In vitro evaluation and sensitivity test of antibiotics \& fungicides against Xanthomonas axonopodis pv. punice isolates

\begin{tabular}{|c|c|c|c|c|c|c|c|c|c|c|}
\hline \multirow[t]{2}{*}{ Sr No } & \multirow{2}{*}{$\begin{array}{l}\text { Name of } \\
\text { treatment }\end{array}$} & \multirow{2}{*}{$\begin{array}{c}\text { Concentration } \\
\text { (ppm) }\end{array}$} & \multicolumn{8}{|c|}{ Zone of inhibition $(\mathrm{mm}) *$ average of three replication } \\
\hline & & & $\begin{array}{c}\text { Xap1 } \\
\text { (Satara) }\end{array}$ & $\begin{array}{c}\text { Xap2 } \\
\text { (Solapur) }\end{array}$ & $\begin{array}{l}\text { Xap3 } \\
\text { (Pune) }\end{array}$ & $\begin{array}{c}\text { Xap4 } \\
\text { (Ahmednagar) }\end{array}$ & $\begin{array}{c}\text { Xap5 } \\
\text { (Jalna) }\end{array}$ & $\begin{array}{c}\text { Xap6 } \\
\text { (Buldhana) }\end{array}$ & $\begin{array}{c}\text { Xap7 } \\
\text { (Washim) }\end{array}$ & $\begin{array}{c}\text { Xap8 } \\
\text { (Akola) }\end{array}$ \\
\hline T1 & $\begin{array}{l}\text { Streptomycin } \\
\text { sulphate }\end{array}$ & 100 & 0.00 & 0.00 & 0.00 & 0.00 & 0.00 & 15.50 & 0.00 & 0.00 \\
\hline $\mathbf{T 2}$ & $\begin{array}{l}\text { Streptomycin } \\
\text { sulphate }\end{array}$ & 250 & 0.00 & 0.00 & 0.00 & 0.00 & 0.00 & 16.67 & 0.00 & 0.00 \\
\hline T3 & $\begin{array}{l}\text { Streptomycin } \\
\text { sulphate }\end{array}$ & 500 & 0.00 & 0.00 & 0.00 & 0.00 & 0.00 & 19.17 & 0.00 & 0.00 \\
\hline T4 & Streptocycline & 100 & 6.00 & 15.67 & 0.00 & 0.00 & 0.00 & 12.67 & 0.00 & 15.00 \\
\hline T5 & Streptocycline & 250 & 15.67 & 20.33 & 15.33 & 18.00 & 16.33 & 18.33 & 11.67 & 20.67 \\
\hline T6 & Streptocycline & 500 & 18.67 & 23.67 & 23.00 & 20.67 & 22.00 & 23.67 & 21.67 & 22.67 \\
\hline T7 & $\begin{array}{l}\text { Copper } \\
\text { Oxychlorite }\end{array}$ & 2500 & 0.00 & 0.00 & 0.00 & 0.00 & 0.00 & 0.00 & 0.00 & 0.00 \\
\hline T8 & $\begin{array}{l}\text { Streptomycin } \\
\text { sulphate + COC }\end{array}$ & $250+2500$ & 31.33 & 34.67 & 31.00 & 34.00 & 33.00 & 39.00 & 30.67 & 28.67 \\
\hline T9 & $\begin{array}{l}\text { Streptocycline + } \\
\text { COC }\end{array}$ & $250+2500$ & 24.00 & 22.33 & 21.67 & 24.67 & 24.00 & 24.00 & 23.00 & 23.33 \\
\hline T10 & Salicyclic acid & 200 & 0.00 & 0.00 & 0.00 & 0.00 & 0.00 & 0.00 & 0.00 & 0.00 \\
\hline T11 & Control & & 0.00 & 0.00 & 0.00 & 0.00 & 0.00 & 0.00 & 0.00 & 0.00 \\
\hline F test & & & Sig. & Sig. & Sig. & Sig. & Sig. & Sig. & Sig. & Sig. \\
\hline $\begin{array}{c}\text { SE(M) } \\
\pm\end{array}$ & & & 0.95 & 0.97 & 0.57 & 0.68 & 0.37 & 0.66 & 0.64 & 0.31 \\
\hline $\begin{array}{c}\mathrm{CD} \\
(\mathbf{P}=\mathbf{0 . 1})\end{array}$ & & & 3.80 & 3.88 & 2.29 & 2.74 & 1.48 & 2.63 & 2.57 & 1.26 \\
\hline
\end{tabular}


Fig.1 Pathogenicity test
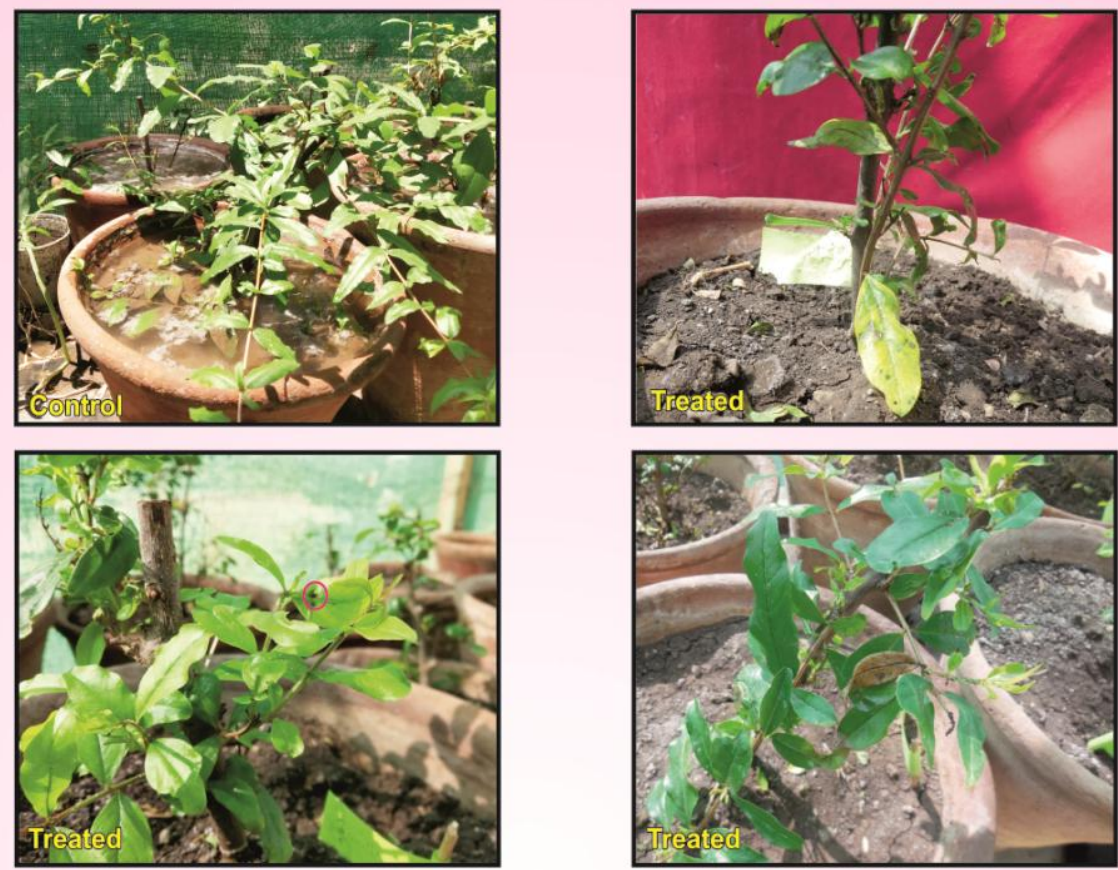

Plate 8 Pathogenicity test of Xanthomonas axonopodis pv. punicae on Pomegranate seedlings
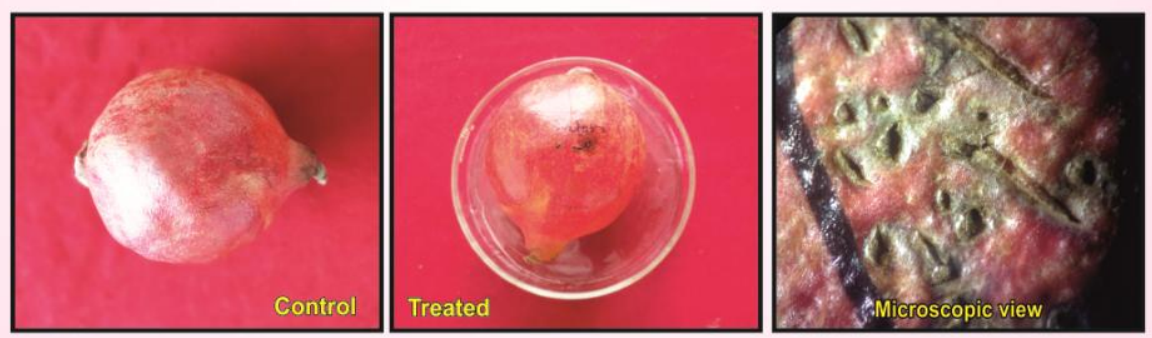

Plate 9 Pathogenicity test of Xanthomonas axonopodis pv. punicae on Fruit of pomegranate

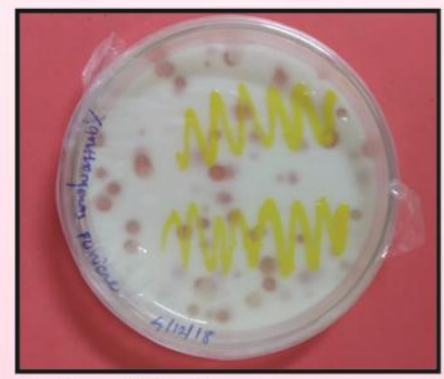

Plate 10 Re-isolation of Xanthomonas axonopodis pv. punicae 
Fig.2 In vitro evaluation and sensitivity test of antibiotics \& fungicides against Xanthomonas axonopodis pv. punice isolates

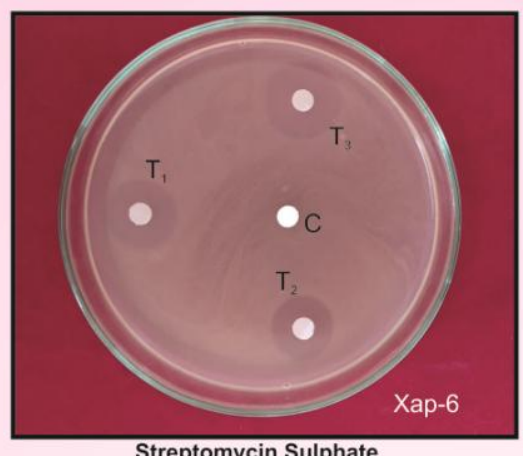

Streptomycin Sulphate

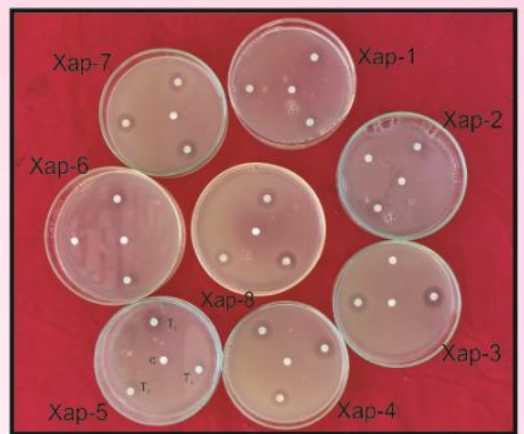

Streptocycline

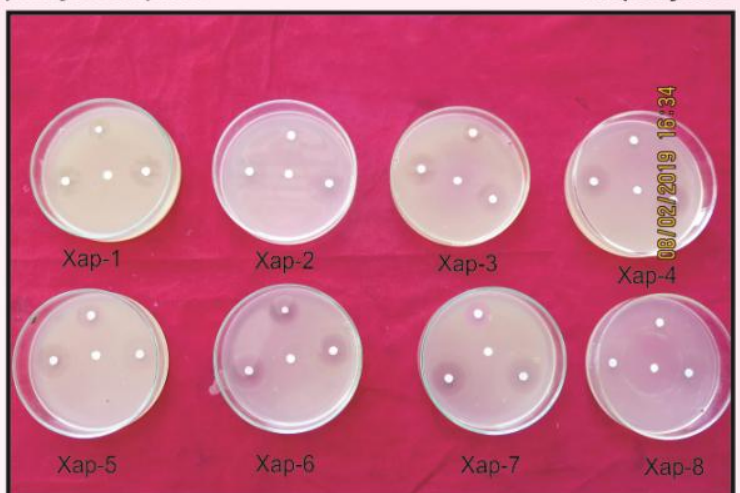

Strptocycline $250 \mathrm{ppm}+$ COC $0.25 \%$

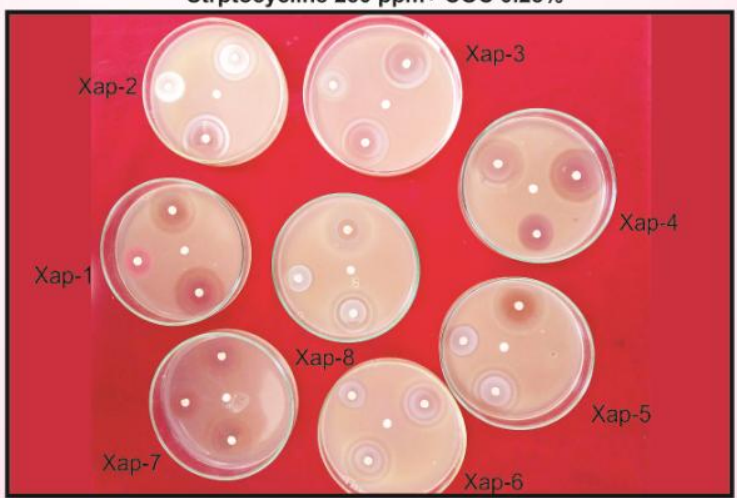

Streptomycin Sulphate $250 \mathrm{ppm}+$ COC $0.25 \%$

$\mathrm{T}_{1}$ - Streptomycin Sulphate $100 \mathrm{ppm}$

$\mathrm{T}_{3}$-Streptomycin Sulphate $500 \mathrm{ppm}$

$\mathrm{T}_{2}$-Streptomycin Sulphate $250 \mathrm{ppm}$

$\mathrm{T}_{4}-$ Strptocycline $100 \mathrm{ppm}$

$\mathrm{T}_{5}$-Strptocycline $250 \mathrm{ppm}$

$\mathrm{T}_{7}-\mathrm{COC} 0.25 \%$

$\mathrm{T}_{6}$-Strptocycline500 ppm

$\mathrm{T}_{8}$-Streptomycin Sulphate $250 \mathrm{ppm}+$ COC $0.25 \%$

$\mathrm{T}_{9}$-Strptocycline $250 \mathrm{ppm}+$ COC $0.25 \%$

$\mathrm{T}_{10}$ - Salicyclic acid $200 \mathrm{ppm}$

$\mathrm{T}_{11}$-Control

Plate 16 In vitro Evaluation and sensitivity test of antibiotics and fungicides against Xanthomonas axonopodis pv. punicae 


\section{References}

Petersen, Y., E. L. Mansvelt, E.Venter, and W. E. Langenhoven 2007. Detection of Xanthomonas axonopodispv. Punicae causing bacterial blight on pomegranate in South Africa. J. of Austrian Pl. Path., 39: 544-546.

Mondal, K. K. and D. Singh 2009. Bacterial blight of pomegranate-A technical bulletin of Division of Plant Pathology, Indian Agricultural Research Institute, New Delhi, pp: 8.

Mondal, K. K. and J. Sharma 2009. Bacterial blight an emerging threat to pomegranate export of Indian Farming, 59: $22-23$.

Mondal, K. and C. Mani, 2012. Investigation of the antibacterial properties of nanocopper against Xanthomonas axonopodispv. punicae, the incitant of pomegranate bacterial blight. Annals of Microbiology, 62: 889-893.

Abhang, P. B., M. V. Totawar, and R. Kadam, 2015. Biochemical characterization of Xanthomonas axonopodispv. citri for identification of Citrus canker disease. J. Basic Sci., 30-33.

Raju, J., B. Enagi, V. I. Jaylakshmi, , K. Angadi, S. G. Basha and P.S. Sonavane, 2012. Survey, surveillance and in vitro evaluation of chemicals against Xanthomonas axonopodispv. punicaecausing bacterial blight of pomegranate. J. Pl. Dis. Sci. 7(2): 225230

Ambadkar C.V., A. S. Dhawan and V.N. Shinde 2015. Integrated management of bacterial blight disease (oily spot) of pomegranate caused by Xanthomonas axonopodispv. punicae. Int. J. Pl. Dis. Sci., 10(1) : 19-23.

Ambadkar, C. V., M. A. Atarand G. A. Bhalerao,2015. Occurrence and distribution of bacterial blight of pomegranate caused by Xanthomonas axonopodispv. punicaein Latur and Osmanabad districts of Marathwada region. Adv. Res. J. crop Improvement 6(1): 50-55.

\section{How to cite this article:}

Sumant H. Kabade, R. W. Ingle, Punam N. Usendi amd Rahul S. Shete. 2020. In vitro Evaluation and Sensitivity of Antibiotics and Fungicides against Xanthomonas axonopodis pv. punicae. Int.J.Curr.Microbiol.App.Sci. 9(08): 2101-2109.

doi: https://doi.org/10.20546/ijcmas.2020.908.239 